UDC 504.064: 614.7

DOI: $10.21668 /$ health.risk/2019.4.06.eng

\title{
SOCIAL-HYGIENIC MONITORING SYSTEM UPDATING BASED ON HEALTH RISK ANALYSIS (at the municipal level)
}

\author{
I.V. Tikhonova ${ }^{1}$, M.A. Zemlyanova ${ }^{2}$ \\ ${ }^{1}$ Federal Service for Surveillance over Consumer Rights Protection and Human Wellbeing, Krasnoyarsk Region \\ office, 21 Karatanova Str., Krasnoyarsk, 660049, Russian Federation \\ ${ }^{2}$ Federal Scientific Center for Medical and Preventive Health Risk Management Technologies, 82 Monastyrskaya Str., \\ Perm, 614045, Russian Federation
}

In order to increase efficiency of activities aimed at reducing impacts exerted by leading health risk factors it is necessary to optimize observation over the existing social and hygienic situation within social and hygienic monitoring $(S G M)$. It is also necessary to substantiate reference points where monitoring posts for controlling ambient air quality should be located within zones influenced by industrial enterprises, primarily those ranked as economic entities that could cause extremely high or high potential health risks.

Methodical approaches to optimizing monitoring programs and location of monitoring posts within SGN system at the municipal level were implemented with complex analysis of health risk factors occurring due to economic activities by an enterprise that dealt with alumina production (Achinsk city in Krasnoyarsk region). The analysis included assessing and ranking potential threats to population health, first of all, to the respiratory organs; substances emitted into the atmosphere by the examined enterprise; consolidated calculations of ground concentrations diffusion; instrumental monitoring and field observations; hazard indexes under acute and chronic combined exposure to substances with one-way damaging impacts on the respiratory organs.

The obtained results allowed creating a specific list of admixtures that should be observed systematically (particulate matter, $P M_{2.5}$ and $P M_{10}$, formaldehyde, manganese, copper, aluminum, nitrogen dioxide, sulfur dioxide, hydrofluoride, xylene, and toluene) and periodically (vanadium (V), nickel, and chromium (IV)). We substantiated two reference points where monitoring posts for controlling ambient air quality should be located within SGM system (instead of 5 existing mobile points) with specific fix-up on a territory; these points characterized a zone influenced by an alumina-producing enterprise. Control over ambient air quality at the chosen reference points within SGM does not require any interaction with an economic entity when surveillance and control activities are being performed; it is advisable to apply an extended program for monitoring over ambient air quality at these points and assess residual risks caused by exposure to substances that could be potentially hazardous for the respiratory organs as such risks can occur when an enterprise develops and implements activities aimed at achieving acceptable levels of risks.

Key words: ambient air quality, social and hygienic monitoring, chemical factors, risks for the respiratory organs, monitoring posts, monitoring program, stationary monitoring posts.

Social and hygienic monitoring pursues the following major goals when performing all its activities: assessing public health and the environment, revealing any changes in their state and making predictions on a future situation, detecting and eliminating hazardous impacts exerted on human health by environmental factors. All these goals are fixed in the RF Federal Law No. 52-FZ "On sanitaryepidemiologic welfare of the population"
(Clause 45). Achieving these goals requires solving such basic tasks as revealing causeand-effect relations between public health and impacts exerted by environmental factors basing on systemic analysis and health risk assessment. These tasks can be solved only provided that systemic instrumental measuring of environmental objects quality yields adequate results, that is, allows obtaining current, relevant, and authentic data [1]. Collected data

(C) Tikhonova I.V., Zemlyanova M.A., 2019

Irina V. Tikhonova - Head of the Social and Hygienic Monitoring Department (e-mail: tihonova_iv@24.rospotrebnadzor.ru; tel.: +7 (391) 226-89-91; ORCID: http://orcid.org0000-0003-4111-8454).

Marina A. Zemlyanova - Doctor of Medical Sciences, Chief Researcher acting as the Head of the Department for Biochemical and Cytogenetic Diagnostic Techniques (e-mail: zem@fcrisk.ru; tel.: +7 (342) 236-39-30; ORCID: http://orcid.org/0000-0002-8013-9613). 
should fully provide necessary foundation for full-fledged hygienic assessment of environmental factors; that is, they are to provide not only insight into concentrations of this or that component (substance or admixture) in an environmental object but also into health parameters associated with a given factor and exposure to it [2].

Given that, it is necessary to constantly improve approaches to selecting control points and to optimize monitoring programs performed within SGM activities [3-6]. A lot of research has proven that when substantiating reference points for control over ambient air quality, a special attention should be paid to housing areas where exposure factors create the greatest health risks and the density of population exposed to such factor is also the highest. When giving grounds for lists and scales of monitoring, it is necessary to spot out chemicals with additivity and/or potentiating of adverse effects under simultaneous longterm introduction into a body and, consequently, imposing the greatest threats for human health [7-9].

Ambient air contamination with chemicals is a persistent health risk factor which has long been considered a significant one among other environmental factors [10-12]. Over the last decade Rospotrebnadzor's bodies and organizations have taken a substantial amount of efforts to develop a unified list of parameters for monitoring over ambient air quality in order to make social and hygienic monitoring more efficient [13-15]. Scientifically grounded methodical approaches to selecting control points and programs for monitoring over ambient air have been developed and tested as a result of activities performed within "Pure air" Federal project; they took into account specific features of already existing social and hygienic monitoring networks; tests have been carried out in several RF regions (at the municipal level) [1]. Such activities become especially significant in industrially de- veloped regions where a lot of admixtures are emitted into the atmosphere with dust and gas emissions; concentrations of these admixtures create unacceptably high health risks, primarily for the respiratory organs. Such regions are cities where metallurgic enterprises are located including those producing alumina. Major economic activities performed in such regions belong to processing industries and economic entities operating there are assigned into a category of objects with extremely high and high potential health risks borne by exposed population [16]. Most chemical factors that contaminate ambient air are components of dust and gas emissions; specific features of technological processes applied at alumina production result in emissions containing particulate matter, di-aluminum-trioxide, gaseous fluorides, nitrogen oxide and dioxide, sulfur dioxide, dimethylbenzene, manganese, etc. Inhalation exposure to such chemical factors is primarily characterized with summation and synergy of adverse impacts exerted by them on the respiratory organs and it causes elevated risks of diseases among exposed population $[11,17-20]$. Children who live in housing areas influenced by emissions from industrial enterprises are the most sensitive to such exposures and run the highest health risks caused by chemical factors ${ }^{1}$. A child's body, including the respiratory system, has certain age-related structural and anatomic peculiarities and its adaptation and detoxification mechanisms are not completely developed [21] thus making it more sensitive to ambient air quality and shortening a period of time during which a response occurs in the respiratory organs to adverse effects produced by exposure to chemical factors.

Given all the above stated, we believe it is necessary to make social and hygienic monitoring aimed at control over ambient air quality more efficient on territories where large industrial facilities are located; these improvements should also cover activities performed within existing programs for regular monitoring.

${ }^{1} \mathrm{G}$ 2.1.10.1920-04. Guide on assessing population health risks caused by exposure to chemicals that pollute the environment. Moscow, The RF Public healthcare Ministry's Federal Center for State Sanitary and Epidemiologic Surveillance, $2004,143 \mathrm{p}$. 
Our research goal was to update an existing SHM system based on health risk analysis at the municipal level.

Data and methods. Methodical approaches to optimizing SHM activities at the municipal level were implemented in a region where a large alumina-producing enterprise was located (a city called Achinsk in Krasnoyarsk region). Achinsk has a population equal to 105.25 thousand people and its territory is 103.2 square kilometers. Major industries in the city are fuel and energy production, metallurgy, oil-processing and wood-processing. The largest enterprise is an alumina-producing plant which is assigned into a category of economic entities with the extremely high potential health risks. We accomplished complex analysis of health risk factors related to economic activities performed by the given enterprise; our analysis included identifying potential threats, primarily for the respiratory organs. We also identified components of emissions from stationary sources in Achinsk and from the aluminaproducing enterprise basing on assessing data on actual gross emissions into the atmosphere (Statistical reports 2-tp (air) submitted in 20122017). To assess exposure and analyze spatial distribution of all obtained parameters, we took initial cartographic information, namely, an electronic map of the city territory (scaled 1:10000). Then we used GIS ArcView 3.2 and ArcGIS 9.3, ESRI to put different objects on it, plotting them in separate layers; these objects were houses, industrial objects, industrial facilities and areas, motorways and streets, monitoring points etc. To select priority admixtures for control, we performed aggregated calculations of ground concentrations dispersions for 26 substances as per data taken from the latest reference book on maximum permissible emissions from the alumina-producing enterprise (2016). The reference book included invento- ries that listed stationary sources of contaminants emissions. We performed our calculations according to "Procedures for calculating dispersions of adverse substances (contaminants) emissions in ambient air" (MRR-2017) ${ }^{2}$ applying "Ecolog 4.50" unified UPRZA software package. We applied "Ekolog - Gorod" UPRZA software package to calculate average annual contaminants concentrations as it had a section for calculating "average values". A meteofile with data on typical meteorological conditions in Achinsk was obtained from Voeykov's Major Geophysical Observatory. Dispersions were calculated at 6,630 calculation points (nodes) in the regular grid; having done that, we applied the results to calculate risk parameters under acute and chronic introduction for each substance according to GP 2.1.10.1920-04. It allowed us to obtain exposure fields that created health risks; we put them on the vector map of the examined territory.

The next step was to select a number of monitoring points and places where to locate them; to do that, we standardized spatiallydistributed parameters and performed cluster analysis on them with STATISTICA software for statistic analysis. This analysis involved applying "nearest centroid classifier" procedure. A number of clusters (a number of stationary posts for monitoring over ambient air quality) required for each territory was determined as per population living there ${ }^{3}$ : one post was required per a territory with its population being lower than 50 thousand people; 2 posts, up to 100 thousand people; $2-3$ posts, $100-200$ thousand people; $3-5$ posts, $200-500$ thousand people; 5-10 posts, more than 500 thousand people; 10-20 posts (stationary and mobile), more than 1 million people. An optimal (reference) point for locating a monitoring post was a point located in a housing area where there was the greatest aggregated risk for the respi-

\footnotetext{
${ }^{2}$ On approval of procedures for calculating dispersions of adverse admixtures (contaminants) emissions in ambient air: The Order by the RF Ministry for Natural Resources and the Environment No. 273 dated June 06, 2017. Garant. Information and legal portal. Available at: https://www.garant.ru/products/ipo/prime/doc/71642906/ (date of visit October 15, 2019).

${ }^{3}$ On organizing laboratory control when performing social and hygienic monitoring activities: The Letter by the Federal Service for Surveillance over Consumer Rights and Human Well-being dated October 2, 2006 No. 0100/10460-06-32. Moscow, Moscow Regional Office of the Federal Service for Surveillance over Consumer Rights and Human Well-being. Available at: http://50.rospotrebnadzor.ru/293/-/asset_publisher/U8Fg/content (date of visit September 20, 2019).
} 
ratory organs which occurred due to all the substances with the same effects and where density of exposed population was the highest in the cluster (more than $75 \%$ ).

To optimize the existing monitoring program, we assessed the current ambient air quality over 2012-2017 and compared calculated and instrumental data. We analyzed information provided by the Federal Information Center of Social and Hygienic Monitoring on a list of points where ambient air quality was controlled by the "Krasnoyarsk Regional Center for Hygiene and Epidemiology" in Achinsk; the given organization controlled ambient air quality within the current social-hygienic monitoring network as per 8 substances. We also took data obtained via instrumental research by the Federal Scientific Center for Medical and Preventive Health Risk Management Technologies accomplished in 2017; the research covered concentrations of 15 substances. We statisti- cally processed and analyzed all the data with STATISTICA software package.

Results and discussion. As a whole, our analysis of gross emissions from industrial enterprises in Achinsk revealed that actual emissions into the atmosphere form stationary sources amounted to approximately 45 thousand tons annually (the third place in Krasnoyarsk region); emissions from alumina production made the greatest contribution into it accounting for $85-86 \%$. There were approximately 85-88 types of chemicals in the list; 45 chemicals out of them were emitted from the major economic entity on the territory. 23 substances were priority ones as per potential hazards of the respiratory organs diseases among population including silicon-containing dusts, nitrogen oxide, sulfur oxide, copper oxide, aluminum oxide, nickel oxide, sodium hydroxide, sulfuric acid, soot, manganese compounds, gaseous fluorides, hydrogen chloride, formaldehyde, etc. (Table 1).

Table 1

List of chemicals that were contained in emissions from the alumina-producing enterprise ranked as per potential hazards of respiratory organs diseases (as per data collected in 2017)

\begin{tabular}{|c|c|c|}
\hline \multirow{2}{*}{ Chemicals } & \multicolumn{2}{|c|}{ Hazard index for a chemical } \\
\hline & Non-carcinogenic & Carcinogenic \\
\hline Non-organic dust: $\mathrm{SiO}_{2}$ lower than $20 \%$ (dolomite) & $11,611,372.5$ & - \\
\hline Nitrogen dioxide & $9,571,171.4$ & - \\
\hline Black oil ash from a thermal power station (recalculated per vanadium) & $7,131,550.0$ & - \\
\hline Nitrogen oxide & $6,441,603.3$ & - \\
\hline Sulfur dioxide & $4,870,348.9$ & - \\
\hline Non-organic dust: $\mathrm{SiO}_{2} 20-70 \%$ (fire clay) & $4,682,106.0$ & - \\
\hline Aluminum oxide (recalculated per aluminum) & $379,543.1$ & - \\
\hline Sodium hydroxide & $232,457.5$ & - \\
\hline Non-organic dust: $\mathrm{SiO}_{2}$ higher than $70 \%$ & $76,139.0$ & - \\
\hline Sulfuric acid & $28,755.8$ & - \\
\hline Back carbon (soot) & $21,279.3$ & - \\
\hline Manganese and its compounds (recalculated as per manganese oxide) & $7,918.0$ & - \\
\hline Copper oxide & $1,065.0$ & - \\
\hline Easily soluble gaseous fluorides (hydrofluoride) & 368.1 & - \\
\hline Hydrogen chloride & 225.8 & - \\
\hline Formaldehyde & 191.7 & 19.2 \\
\hline Никель оксид & 106.5 & 10.7 \\
\hline Particulate matter & 85.2 & - \\
\hline Hydrogen sulfide & 63.1 & - \\
\hline Nitric acid & 28.8 & - \\
\hline Chromium (VI) (recalculated per chromium oxide) & 10.7 & $10,666.7$ \\
\hline Methyl benzene (toluene) & 0.55 & - \\
\hline Dimethyl benzene (xylol) & 0.11 & - \\
\hline
\end{tabular}


We compared a list of priority contaminants emitted into ambient air by aluminumproducing enterprises and a list of substances which were subject to control within SHM system for monitoring air contaminants; it allowed us to reveal certain items in the existing program for control over ambient air quality which were not relevant to the current situation.

We determined that regular control covered only 4 admixtures (17.4\%) out of 23 substances that were potentially hazardous for the respiratory organs and were emitted into ambient air by the alumina-producing enterprise in 2012-2018; these 4 admixtures were nitrogen dioxide, sulfur dioxide, particulate matter, and formaldehyde.

In 2017 the monitoring program included aluminum and easily soluble gaseous fluorides. We detected significant discrepancies between calculated and instrumental data on admixtures concentrations in ambient air. Calculated data didn't reveal any concentrations which exceeded hygienic standards for most examined substances excluding nitrogen dioxide and non-organic dusts that contained less $20 \%$ silicon. Dispersion calculations predicted violations of hygienic standards (in zones where monitoring posts were located) only as per contents of silicon-containing dusts (up to 1 single maximum MPC) and nitrogen dioxide (up to 3.2 average daily MPC). But still there were substances detected at SHM posts for control over ambient air in actual concentrations being higher than single maximum and/or average daily MPC; these elevated concentrations were detected in housing areas in the city in the examined period and a list of substances with such concentrations included nitrogen oxide, particulate matter, formaldehyde, and gaseous fluorides (on average from 4.16 to 10.4 single maximum MPC and from 1.38 to 43.6 average daily MPC); aluminum and sulfur dioxide (from 1.16 to 3.6 average daily MPC). Experts from the Federal scientific Center for Medical and Preventive Health Risk Management Technologies accomplished field observations in 2017 and detected violations of hygienic standards as per concentrations of toluene and xylol (from 3.04 to 4.32 single maximum MPC); solid and gaseous fluorides, particulate matter and its fractions PM2.5 and PM10 (from 1.78 to 4.97 single maximum MPC and from 3.11 to 8.92 average daily MPC); aluminum and manganese (from 1.12 to 3.06 average daily MPC). These violations were detected at 2 out of 4 mobile SHM posts and they were not predicted by any dispersion calculations. The experts also registered persistent occurrence of vanadium (V), chromium (VI) (up to $0.03-0.06$ average daily MPC), and copper (up to 0.44 average daily MPC) in ambient air.

Aggregated calculations of dispersion didn't predict hygienic standards being violated practically as per all the components in emissions from the alumina-producing enterprise. But in spite of that, taking risk criteria into account, we assumed there was an unacceptable risk of respiratory organs diseases for children under combined acute inhalation exposure (HI is up to 11.2) and chronic inhalation exposure (HI is up to 5.02) to priority potentially hazardous chemicals (Figure 1).

Results of monitoring and field observations allowed revealing substantially elevated chronic risks of respiratory organs diseases (HI is up to 31.2-49.9) due to simultaneous occurrence of a wide range of substances with similar adverse effects on the respiratory organs.

The greatest contribution into hazard index are made by particulate matter and their fractions PM2.5 and PM10, formaldehyde, manganese, copper $(9.05-17.91 \%)$, aluminum, nitrogen dioxide, sulfur dioxide, easily soluble gaseous fluorides (1.82-5.57\%). Contributions made by vanadium (V), chromium (VI), xylol, toluene, and sodium hydroxide amount to $0.44-0.92 \%$.

Given all the above mentioned, the monitoring program aimed at control over ambient air quality and accomplished within SHM activities in a zone influenced by the aluminaproducing enterprise needs to be expanded as it should necessarily include regular control over concentrations of manganese, copper, toluene, and xylol. These substances, according to data collected via field observations, are registered at monitoring posts in concentrations which are higher than hygienic standards 


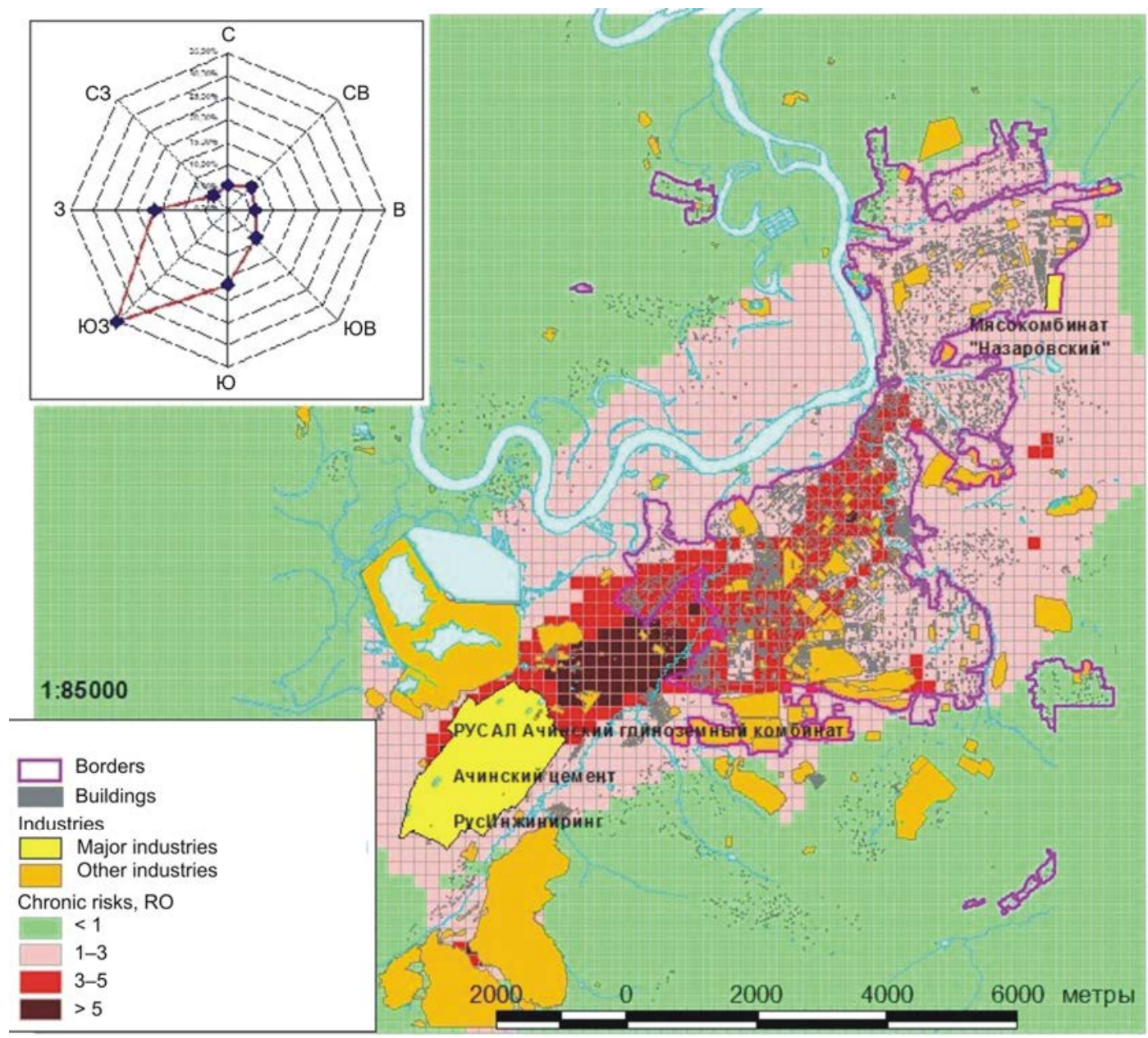

Figure 1. Map showing spatial distribution of hazard index for children's respiratory organs created by emissions from alumina-producing enterprise

(manganese, xylol, and toluene) and/or allow predicting a substantial contribution into aggregated non-carcinogenic risks for the respiratory organs (copper). Such admixtures as vanadium (V), nickel, and chromium (VI) belong to the $1^{\text {st }}$ hazard category and are carcinogenic (nickel and chromium); therefore, it is advisable to include them into systematic monitoring programs to perform control over sanitary-hygienic situation and to determine residual risks in exposure zones.

We determined reference points which were the most suitable for locating monitoring posts included into SHM system for control over ambient air quality in a zone influenced by the alumina-producing enterprise; overall, there were 6 such points for SHM monitoring posts which characterized 2 clusters. Cluster No. 1 was characterized with only 1 point whereas cluster No. 5 was char- acterized with the remaining 5 points. Expert estimates and population density analysis allowed substantiating a choice on only 1 point which was the most representative one in cluster No. 2 (Figure 2; Table 2).

We compared places where proposed monitoring posts would be located and mobile monitoring posts where control over ambient air quality was performed within SHM activities as we tried to make recommendations on how to optimize the monitoring program for a territory influenced by the examined aluminaproducing enterprise. We revealed they were convergent; consequently, it was quite possible to use data which were obtained at already existing monitoring posts.

Conclusions. We accomplished a piece of research at the municipal level in a region where a large alumina-producing enterprise was located; that enterprise could potentially 


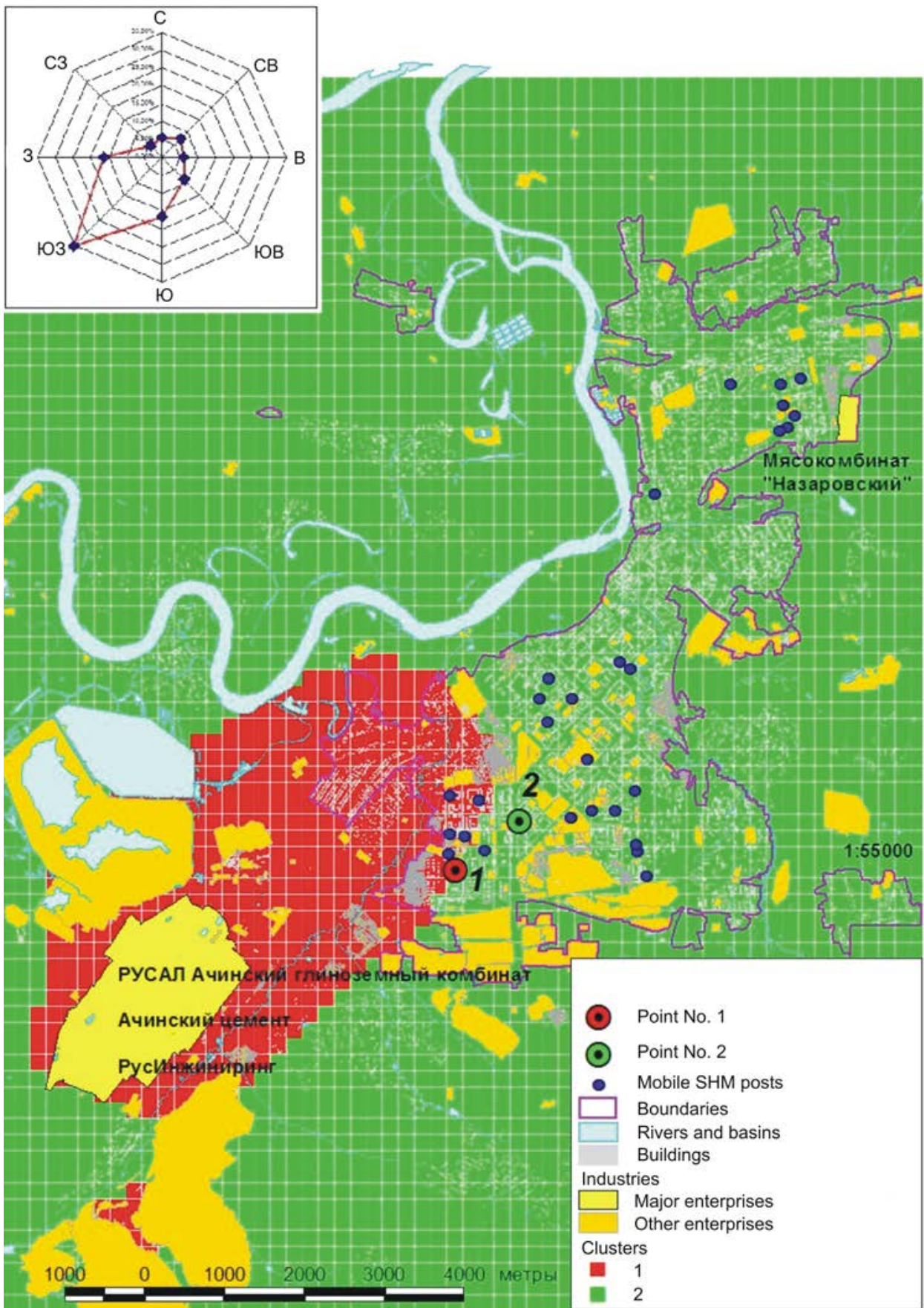

Figure 2. Representative points for locating ASHM monitoring posts aimed at control over ambient air quality in a zone influenced by alumina-producing enterprise

Table 2

Points proposed for locating SHM monitoring posts for control over ambient air quality in Achinsk

\begin{tabular}{|c|c|c|c|c|c|c|}
\hline \multirow{2}{*}{$\begin{array}{l}\text { Point } \\
\text { No. }\end{array}$} & \multirow{2}{*}{ Cluster } & \multicolumn{2}{|c|}{ Coordinates, $\mathrm{m}$} & \multirow{2}{*}{$\begin{array}{c}\text { Rank } \\
\text { sum }\end{array}$} & \multirow{2}{*}{$\begin{array}{c}\text { Population } \\
\text { density quotient }\end{array}$} & \multirow{2}{*}{$\begin{array}{l}\text { Address of the closest } \\
\text { apartment block }\end{array}$} \\
\hline & & $\mathrm{X}$ & $\mathrm{Y}$ & & & \\
\hline 4163 & 1 & 14,800 & 35,700 & 186 & 1.0 & Stroitelei str. 25 \\
\hline 4478 & 2 & 15,600 & 36,300 & 188 & 0.87 & The $5^{\text {th }}$ micro-district, 19 \\
\hline
\end{tabular}


cause extremely high health risks. Our research allowed us to substantiate two reference points for control over ambient air quality (instead of existing 5 mobile control posts) with a concrete location; these two points characterized a zone influenced by the examined alumina-producing enterprise.

It is advisable to apply an expanded program for control over ambient air quality in recommended monitoring points within SHM system which is implemented without any interaction with the alumina-producing enterprise being subject to surveillance within control and surveillance activities. This expanded program should include systematic monitoring over particulate matter, PM2.5 and PM10 fractions, formaldehyde, manganese, copper, aluminum, nitrogen dioxide, sulfur dioxide, easily soluble gaseous fluorides (hydrofluoride), xylol, and toluene; and periodical monitoring (once a three years) over vanadium (V), nickel, and chromium (VI). It is also necessary to assess residual risks caused by exposure to substances which are potentially hazardous for the respiratory organs when experts at the examined enterprise develop and implement activities aimed at reducing risks up to their acceptable levels.

Gratitude. The authors express their deepest gratitude to $\mathrm{S}$. Yu. Balashov, the senior researcher at the Federal Scientific Center for Medical and Preventive Health Risks Management Technologies for the assistance he rendered in accomplishing this work.

Funding. The research was not granted any sponsor support.

Conflict of interests. The authors declare there is no any conflict of interests.

\section{References}

1. Onischenko G.G. Conception of health risks and its place in the system of sociohygienic monitoring (problems and approaches to their solution). Vestnik Rossiiskoi akademii meditsinskikh nauk, 2005, no. 11 , pp. 27-33 (in Russian).

2. Zaitseva N.V., May I.V., Kleyn S.V., Goryaev D.V. Methodical approaches to selecting observation points and programs for observation over ambient air quality within social and hygienic monitoring and "pure air" federal project. Health Risk Analysis, 2019, no. 3, pp. 4-17 (in Russian). DOI: $10.21668 /$ health.risk/2019.3.01.eng

3. Zhavoronok L.G. Sotsial'no-gigienicheskii monitoring - instrument upravleniya kachestvom sredy obitaniya i zdorov'ya naseleniya [Social and hygienic monitoring as a toll for managing quality of the environment and population health]. Uchenye zapiski Rossiiskogo gosudarstvennogo sotsial'nogo universiteta, 2009, vol. 68, no. 5, pp. 124-129 (in Russian).

4. Nechukhaeva E.M., Maslov D.V., Afanas'eva S.I. Aktual'nye zadachi sotsial'no-gigienicheskogo monitoring na regional'nom urovne [Vital tasks to be solved by social and hygienic monitoring at the regional level]. Zdorov'e. Meditsinskaya ekologiya. Nauka, 2010, vol. 41-42, no. 1-2, pp. 39-40 (in Russian).

5. Kuz'min S.V., Privalova L.I., Katsnel'son B.A., Nikonov B.I., Gurvich V.B., Voronin S.A., Malykh O.L., Korzhikov A.S. [et al.]. Risk assessment and environmental and epidemiological studies as interrelated tools of sociohygienic monitoring at the local and regional levels. Gigiena $i$ sanitariya, 2004, no. 5, pp. 62-64 (in Russian).

6. Gurvich V.B., Kuz'min S.V., Malykh O.L., Yarushin S.B. Public health monitoring - integrated assessment and management of risk for health at the regional level. Sanitarnyi vrach, 2014, no. 1, pp. 29-31 (in Russian).

7. Zabolotskikh V.V., Vasil'ev A.V., Tereshchenko Yu.I. Synergetic effects during combined impact of physical and chemical factors. Izvestiya Samarskogo nauchnogo tsentra Rossiiskoi akademii nauk, 2016, vol. 18, no. 5 (2), pp. 290-295 (in Russian).

8. Matthias A.D. Monitoring near-surface air quality. Environmental monitoring and characterization, 2004, pp. 163-181. DOI: 10.1016/B978-012064477-3/50012-6

9. Vallero D. Fundamentals of Air Pollution, 4th edition. USA, Academic Press Publ., 2014, 996 p.

10. Kiku P.F., Anan'ev V.Yu., Zhigaev D.S., Shiter N.S., Bogdanova V.D., Zavyalova Y.S. Assessment of health risks of the population of Vladivostok when exposed to atmospheric air. Zametki uchenogo, 2015, no. 3, pp. 157-160 (in Russian). 
11. Kapranov S.V., Nozhenko A.A. Otsenka riska dlya zdorov'ya naseleniya ot zagryazneniya atmosfernogo vozdukha $\mathrm{v}$ gorode $\mathrm{s}$ krupnymi proizvodstvami chernoi metallurgii i koksokhimii [Assessing population health risks caused by ambient air contamination in a city with large industrial enterprises involved in ferrous metallurgy and coke chemistry]. Gigiena naselennykh mest, 2013, no. 62, pp. 50-54 (in Russian).

12. Kos'kina E.V., Ivoilov V.M., Mikhailuts A.P., Glebova L.A., Bogomolova N.D., Gromov K.G., Gracheva T.Yu. Environment and health monitoring and evaluation aerogenic risk to public health and steel major centers in substantiating the sanitary protection zone of the plant. Sovremennye problemy nauki i obrazovaniya, 2012, no. 3, pp. 31-32 (in Russian).

13. Igonin E.I., Shlychkov A.P., Shagidullin A.R., Shagidullin R.R. Optimization of the regional atmospheric air monitoring system on the example of Nizhnekamsk. Rossiiskii zhurnal prikladnoi ekologii, 2016, vol. 7, no. 3, pp. 33-39 (in Russian).

14. Zaitseva N.V., May I.V. Regional'nyi opyt ucheta pokazatelei riska dlya zdorov'ya naseleniya v zadachakh prostranstvennogo planirovaniya [Regional experience in incorporating population health risk parameters into solving tasks related to spatial planning]. Ars Administrandi. Iskusstvo upravleniya, 2011, no. 2, pp. 30-39 (in Russian).

15. Zaitseva N.V., May I.V., Kleyn S.V. Optimization of resident area air quality supervision programs in socio-hygienic monitoring system on the basis of spatial analysis and inhabitant's health risk assessment. Permskii meditsinskii zhurnal, 2010, vol. 27, no. 2, pp. 130-138 (in Russian).

16. Goryaev D.V., Tikhonova I.V., Kir'yanov D.A. Industrial enterprises and health risk categories. Gigiena i sanitariya, 2017, vol. 96, no. 12, pp. 1155-1158 (in Russian). DOI: 10.18821/0016-99002017-96-12-1155-1158

17. Air quality guide lines for particulate matter, ozone, nitrogendioxide and sulfurdioxide: Summary of risk assessment. World health organization, 2005. Available at: http://apps.who.int/iris/handle/10665/69477 (15.10.2019).

18. Shalina T.I. The hygienic estimate of the risk for human health among the population in the areas connecting with aluminium production. Sibirskii meditsinskii zhurnal (Irkutsk), 2009, vol. 91, no. 8, pp. 128-129 (in Russian).

19. Guan W.J., Zheng X.Y., Chung K.F., Zhong N.S. Impact of air pollution on the burden of chronic respiratory diseases in China: time for urgent action. Lancet, 2016, vol. 388, no. 10054, pp. 1939-1951. DOI: $10.1016 / \mathrm{S} 0140-6736(16) 31597-5$

20. Dick S., Doust E., Cowie H., Ayres J.G., Turner S. Associations between environmental exposures and asthma control and exacerbations in young children: a systematic review. BMJ Journals, 2013, no. 4, pp. e003827. DOI: 10.1136/bmjopen-2013-003827

21. Pul'monologiya. Natsional'noe rukovodstvo. Kratkoe opisanie [Pulmonology. National guidebook. Short description]. In: L.G. Huchalin ed. Moscow, GEOTAR-MediaPubl., 2014, 800 p. (in Russian).

Tikhonova I.V., Zemlyanova M.A. Social-hygienic monitoring system updating based on health risk analysis (at the municipal level). Health Risk Analysis, 2019, no. 4, pp. 60-68. DOI: 10.21668/health.risk/2019.4.06.eng

Received: 15.11 .2019

Accepted: 27.11.2019

Published: 30.12.2019 
UDC 613.21

DOI: 10.21668/health.risk/2019.4.07.eng

\title{
ASSESSING RISK FACTORS THAT CAN CAUSE ALIMENTARY-DEPENDENT DISEASES AMONG STUDENTS DUE TO THEIR NUTRITION
}

\author{
O.V. Mitrokhin, A.A. Matveev, N.A. Ermakova, E.V. Belova
}

I.M. Sechenov First Moscow State Medical University, bld. 2, 2 Bol'shaya Pirogovskaya Str., Moscow, 119435, Russian Federation

This research can be considered quite vital due to digestive organs diseases being widely spread among young students. We chose students attending I.M. Sechenov's First Moscow State Medical University as our research object. We questioned 840 students who attended the above-mentioned higher education establishment and assessed their medical check-ups data; having done that, we analyzed risks of alimentary-dependent diseases among students related to impacts exerted by their nutrition.

Our research goal was to assess students' nutrition, its structure, frequency, and conditions; to determine priority risk factors for students' health; and to develop recommendations on healthy nutrition provided for them as a factor related to pursuing healthy lifestyle.

We detected that about $20 \%$ students didn't have breakfast; about $8 \%$ didn't have lunch or dinner (and it meant they had less than 3 meals a day; however, half of the students had 3 meals a day. $65.7 \%$ of the students had their last meal a day after 9 p.m., and about $20 \%$, after 23 (late meal). We ranked a correlation between nutrition-related risk factors and existing nosologies and revealed that 3 factors exerted the most significant influence on the digestive organs diseases; they were late meals, irregular hot meals, and a number of meals taken a day. Endocrine system diseases were mostly influenced by 2 factors, late meals and a number of meals a day. Number of meals a day was also correlated to respiratory organs diseases and urogenital system diseases; late meals, to diseases in the nervous and cardiovascular systems.

Key words: risk assessment, students, number of meals a day, nutrition regime, late meals, meal, morbidity, health preservation, healthy lifestyle, prevention.

Nowadays an issue related to rational and balanced nutrition consumed by various population groups as well as adherence to good nutrition is a priority in research accomplished in the sphere of nutrition including studies aimed at preventing the most widely spread noninfectious diseases [1].

Given that, it is necessary to accomplish task-oriented applied scientific research aimed at detecting and assessing influences exerted on population health by food products which are able to create intolerable (unacceptable) risks for people's life and health $^{1}$

As a result, such research should allow achieving mass adherence to good nutrition as a factor that helps pursue healthy lifestyle ${ }^{2}$.

Methodology for assessing risks caused by impacts exerted by environmental factors on population health is an efficient tool for assessing influence on a human body including adverse impacts exerted on health by nonrational and imbalanced nutrition.

(C) Mitrokhin O.V., Matveev A.A., Ermakova N.A., Belova E.V., 2019

Oleg V. Mitrokhin - Doctor of Medical Sciences, Professor at the Common Hygiene Department (e-mail: mov1163@yandex.ru; tel.: +7 (499) 248-19-65; ORCID: https://orcid.org/0000-0002-6403-0423).

Aleksandr A. Matveev - Doctor of Medical Sciences, Professor at the Common Hygiene Department (e-mail: matveevmed@mail.ru; tel.: +7 (916) 832-50-82; ORCID: https://orcid.org/0000-0002-0309-4474).

Nina A. Ermakova - Senior Lecturer at the Common Hygiene Department (e-mail: ninaok11@gmail.com; tel.: +7 (916) 150-07-06; ORCID: https://orcid.org/0000-0002-9745-4265).

Elena V. Belova - Assisstant lecturer at the Common Hygiene Department (e-mail: ms.ekochina@mail.ru; tel.: +7 (985) 085-39-95; ORCID: https://orcid.org/0000-0002-2134-6348).

${ }^{1}$ The strategy aimed at increasing food products quality in the Russian Federation up to 2030. Approved by the RF Government Order dated June 29, 2016 No. 1364-p. Moscow, 2016, 17 p.

${ }^{2}$ On sanitary-epidemiologic welfare of the population in the Russian Federation in 2019: The State report. Moscow, 2019,254 p. 